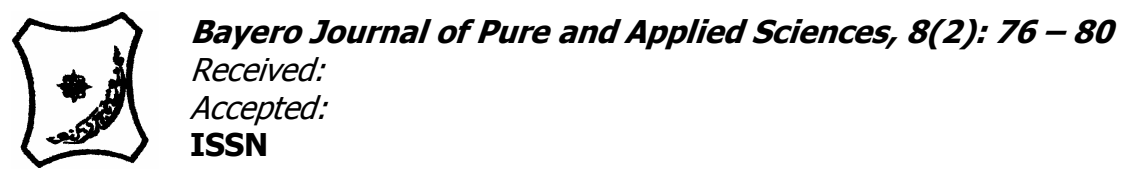

\title{
QUALITY EVALUATION OF DAKUWA AND EFFECT OF RATIOS OF TIGERNUT TO GROUNDNUT IN DAKUWA PRODUCTION
}

\author{
Igwe $^{1}$,E. C., Tari, M. A. ${ }^{2}$ and Dandago, M. A. ${ }^{3}$ \\ ${ }^{1}$ Dept of Food Science and Technology, \\ Nnamdi Azikiwe University, Awka, \\ Anambra State, Nigeria. \\ e-mail=chukwusoro@yahoo.com; Phone: 08038720862 \\ ${ }^{2}$ Department of Food Science and Technology, \\ Modibo Adama University of Technology, Yola, \\ Adamawa State, Nigeria. Phone: 08038720862 \\ ${ }^{3}$ Dept of Food Sci. and Technology, \\ Kano University of Science and Technology, Wudil, \\ Kano State, Nigeria. \\ e-mail=dandago223@yahoo.com; Phone: 08029171797
}

\begin{abstract}
Evaluation of market and laboratory-processed samples of Dakuwa and effects of ratios of tiger nut to groundnut mix (4:1, 3:1, 2:1 and 1:1) on their organoleptic acceptability were carried out through field, laboratory and sensory studies. Results showed tiger nut and groundnuts were major cereals used for Dakuwa production, though sorghum and maize in place of tiger nuts were used by few producers. Ratios of tiger nut to groundnut varied (3:1, 2:1 and 4:1) but ratio 2:1 was most popular. Significant differences were observed for moisture, lipid, protein, ash and pH of both laboratory and market samples (P $\leq 0.05$ ). High microbial load of market samples suggested unsanitary production and handling. Laboratory and market samples were respectively for moisture: 11.67 to 16.50 and 23.33 to 39.20; for lipid: 24.86 to 30.04 and 24.97 to 32.56; for protein: 7.80 to 9.00 and 7.90 to 10.27; ash; 1.63 to 2.50 to 3.48; and pH: 5.79 to 5.95 and 6.15 to 6.59 while higher microbial loads were observed for market samples. Except MD-DD, all samples of Dakuwa were acceptable as their sensory scores were less than 4.0 on a 7-point scale. Significant differences were observed on general acceptability for both the market and laboratory samples (P $\leq 0.05$ ). MD-BB was most liked for market samples whereas LD-BB was most liked for laboratory sample. The least liked ratio of tiger nut to groundnut in Dakuwa formulation was 4:1. In conclusion, no significant differences $(P \geq 0.05)$ were observed between Dakuwa samples made from ratios 3:1, 2:1 and 1:1 but numerically ratio 2:1 was the most acceptable.

Keywords:Dakuwa, Groundnut, Tigernut, quality.
\end{abstract}

\section{INTRODUCTION}

Dakuwa is a traditional snack, prominent in northern Nigeria. It is made from roasted tiger nut and groundnut; it can also be made from roasted sorghum and maize (Bagirie and Adegoke, 2008). In the production of dakuwa, the quantity of tiger nut is usually higher than that of groundnut probably due to the high fat content of the groundnut of which if too high may render the product unacceptable. To this effect some communities use defatted groundnut paste in an effort to reduce the oil content of the final product Nuru (1985). It is produced by cleaning and roasting tiger nut and groundnut separately. They are milled together with spices (ginger and pepper) and is pounded with sugar added to it. Mixing of various proportions of legumes is pounded continuously until a thick, stiff mass is obtained Nuru (1985). It was reported that the pounding continues until it becomes sticky, then it is molded and packed (Bagirie and Adegoke, 2008).
In their assessment of market samples of dakuwa produced in Niger State Nigeria, Ocheme and coworkers reported non uniformity in proximate and mineral (sodium, potassium, calcium and phosphorus) compositions, microbial loads and sensory values ( $P \leq$ 0.05) of products (Ocheme et al., 2011).

Dakuwa production is a major occupation for many women and young girls who can be seen hawking the products throughout the northern states of Nigeria. It is a shelf-stable product and can be kept for about six (6) months at room temperature (Nuru, 1985). "Dakuwd" commands great economic importance among the local communities of northern Nigeria as the product features prominently in social functions such as wedding and other ceremonies. It is used during traditional festival such as "gulla-gulla" (traditional festival), "share" (traditional festival), and "Dogo-Dogo" in Michika local government area Adamawa State and occasion like the installation of chiefs and emirs (Nuru, 1985). 
Local snacks generally face a lot of problems that militate against their development. Those problems specific to dakuwa include differences in raw materials, processing operations hygiene, etc and these result in not only non uniform but also poor quality products. Therefore, the objectives of this research are to find out different methods of dakuwa production, to find out the effect of ratios of groundnut to tiger nut mix on dakuwa acceptability and to evaluate self-laboratory and market samples of dakuwa.

\section{MATERIALS AND METHODS}

The raw materials used for this research were: groundnuts, tiger nut, white crystal sugar and spices (ginger and pepper) which were obtained from the Jemita modern market Yola, Adamawa State. Reagents for analysis were obtained from the Department of Food Science and Technology laboratory of Modibo Adama university of Technology (MAUTECH) Yola, Adamawa State, Nigeria.

Market samples of dakuwa used for this research were collected from four different producers who sell their dakuwa in the commercial centre of Modibo Adama university of Technology (MAUTECH) Yola, Adamawa State, Nigeria. They four dakuwa samples were labeled MD-AA, MD-BB, MD-CC and MD-DD.

\section{Oral Interview}

Oral interview was conducted on five producers of dakuwa selling the product at Modibo Adama University of Technology (MAUTECH), Yola, Nigeria commercial centre. Information sought was on their methods of production, types and ratios of raw materials employed in their production. Also different market samples from four interviewed producers/sellers were selected for study of chemical and sensory evaluations.

\section{Raw Materials Preparations}

Before the dakuwa processing, the raw materials were prepared first. The method of Abodurin and Belewu were adopted in production of roasted tiger nut [4]. Here, tiger nut was sorted and graded to remove impurities. It was weighed and roasted for 12-14 minute at $130^{\circ} \mathrm{C}$ before sifting to remove debris.

Groundnut, which is the second important raw material, was sorted and cleaned to remove impurities. It was weighed roasted for about $10-14$ minutes at $120^{\circ} \mathrm{C}$ and dehulled manually using hands Okaka (1997). For the spices, dried ginger and pepper were pounded into powder and then sieved using a sieve to remove large particles (Bagirei and Adegoke,2008).

\section{Dakuwa processing}

This was done as described by Bagirei and Adegoke (2008). The tiger nut and groundnut were milled together. The spices were added to the milled tiger nut and groundnuts and then pounded until it became sticky. Then it was molded with hands and packaged in a polythene bag. The processing flow chart is as shown in Figure 1 and the ratios of roasted groundnut to tiger nut used for Dakuwa processingin the laboratory and their corresponding sample labels are given in Table 1.

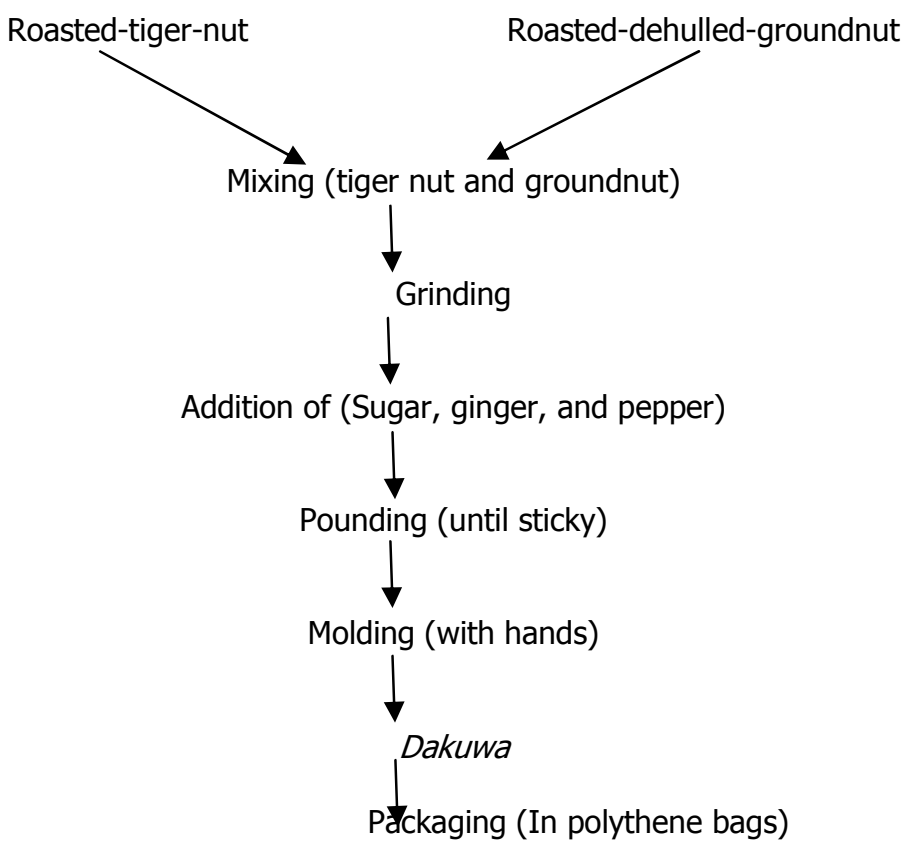

Figure 1: Flow chart for Dakuwa processing.

Table 1: Tiger nut to groundnut ratio used in laboratory preparation of Dakuwa

\begin{tabular}{lllll}
\hline S/No & Groundnut weight $(\mathrm{G})$ & Tiger nut weight $(\mathrm{T})$ & Ratios of $(\mathrm{T})$ to $(\mathrm{G})$ & Labels \\
\hline 1. & $1 \mathrm{~kg}$ & $250 \mathrm{~g}$ & $4: 1$ & LD-AA \\
2. & $1 \mathrm{~kg}$ & $333.33 \mathrm{~g}$ & $3: 1$ & LD-BB \\
3. & $1 \mathrm{~kg}$ & $500 \mathrm{~g}$ & $2: 1$ & LD-CC \\
4. & $500 \mathrm{~g}$ & $500 \mathrm{~g}$ & $1: 1$ & LD-DD \\
\hline
\end{tabular}




\section{Methods of analyses}

Physicochemical analyses were as reported by Kirk (1991) and AOAC (1990). Moisture content determination was by hot-air oven method while lipid analysis was by soxhlet apparatus and protein content determination by Micro-Kjedahl method. Ash content determination was done using a muffle furnace while the digital $\mathrm{pH}$ metre was used for $\mathrm{pH}$ measurement Kirk (1991). A seven-point Hedonic scale was used to evaluate organoleptic acceptability of both market and laboratory samples of dakuwa. Sensory factors were; taste, flavor, color, appearance, texture (mouth feel), softness (finger feel) and general acceptability. Sensory scores ranged from $1=$ liked much to $7=$ disliked much. Total plate bacterial count for both market and laboratory samples was carried out Diliello (1982).

\section{RESULTS AND DISCUSSION Oral Interview}

It was found out that the raw materials for the production of dakuwa were mainly tiger nut and groundnuts. Also sorghum and maize were used also used by few of the producers in place of tiger nuts. Findings also showed that the ratios of tiger nut to groundnut varied and included 3:1, 2:1 and $4: 1$ but ratio 2:1 was most popular.

Oral interview results also showed that the processing operations for dakuwa differ from place to place based on the raw materials, their ratios and spices. Some producers use tiger nut and groundnut only, others uses maize and sorghum and others add sugar and spices while others do not. Report shows that three of the producers roast the tiger nut and groundnut for about 12-15 minutes, they are then cleaned by removing the impurities, it is then milled them separately and pounded with sugar until it becomes sticky. One of the producers, after roasting the tiger nut, maize and groundnut, it was then milled together with sugar and spices added to it, it was then pounded until it becomes sticky.

Personal observation showed that the safety of most of these products is questionable. They were not produced under sanitary and healthy environment. The processing utensils were not clean. For example, two of the producers did not wash their hands before moulding the dakuwa into balls. One of the producers worked in a dirty environment and one of the producers did not clean the dishes used.

\section{Physicochemical analyses}

Table 2 gives the percentage moisture, lipid, protein and ash compositions of market and laboratory processed dakuwa samples. The $\mathrm{pH}$ and total bacterial plate count of dakuwa samples are also given table 2 . Significant differences were observed for moisture, lipid, protein and ash contents as well as for the $\mathrm{pH}$ of the dakuwa samples ( $P \leq 0.05$ ). The values of the moisture contents of the market samples of dakuwa were much higher (23.33 to 39.20$)$ when compared to the values (11.67 to 16.50 ) of laboratory processed dakuwa samples.

But this trend in variation for the between the dakuwa samples was also observed for total bacterial count, partially observed for the $\mathrm{pH}$ and not observed for protein, lipid and ash contents (Table 2).

The high microbial load of the market samples is an indication of unsanitary production handling of the samples. Additionally, all the dakuwa samples were slightly acidic but the pHs of market samples were comparatively slightly lower than the laboratory processed samples.

Table 3 refers to the mean sensory scores of 15 taste panelists on the market samples of dakuwa. The samples were not uniform as significant differences were observed flavour, appearance, taste, colour and general acceptability while there was no significant difference observed for the texture i.e. mouth-feel and finger-feel $(P=0.05)$. This result confirms the findings of Ocheme et al. (2011). Generally the most disliked sample was the MD-DD, which the best sensory score was 3.50 for firmness and the worst was 4.40 for flavour. Also the best organoleptically rated dakuwa market sample was the MD-BB, which the best sensory score was 2.10 for colour and the worst was 3.0 for both taste and texture.

Table 4 gives the sensory values of laboratory prepared dakuwa samples with different ratios of tiger nut to groundnut formulations. Significant differences were observed only in appearance, colour, softness and general acceptability $(P \leq 0.05)$.

The mean sensory scores for all the sensory factors and for all the samples were all less than 4.0 on a sevenpoint Hedonic scale. In general the least liked ratio of groundnut to tiger nut in dakuwa formulation was the $4: 1$, where all the sensory factors were least rated. In conclusion, there were no significant differences observed between dakuwa samples made from ratios $3: 1,2: 1$ and $1: 1$. This finding is contrary to the report of Adegoke and Bagirei (2008) and Nuru (1985) that ratio $2: 1$ is most acceptable in dakuwa formulation. 
Table 2: Total bacterial count, $\mathrm{pH}$ and percentage moisture, lipid, protein and ash compositions of market and laboratory processed dakuwa samples.

\begin{tabular}{|c|c|c|c|c|c|c|c|c|c|c|c|c|}
\hline $\begin{array}{l}N \\
0\end{array}$ & $\begin{array}{l}\text { Sample } \\
\mathrm{s}\end{array}$ & $\begin{array}{l}(\mathrm{T}) \text { to }(\mathrm{G}) \\
\text { ratio }\end{array}$ & \%М.C & & \%Fat & & \%Protein & & $\% A s h$ & & $\mathrm{pH}$ & TPC \\
\hline 1 & MD-AA & $\mathrm{N} / \mathrm{A}$ & $\begin{array}{l}23.33 \\
1.53^{d}\end{array}$ & \pm & $\begin{array}{l}27.85 \\
0.23^{b}\end{array}$ & \pm & $\begin{array}{l}7.90 \\
0.10^{\mathrm{a}}\end{array}$ & \pm & $\begin{array}{l}3.27 \\
0.21^{f}\end{array}$ & \pm & $6.15 \pm 0.15^{c}$ & TNTC \\
\hline 2 & MD-BB & $\mathrm{N} / \mathrm{A}$ & $\begin{array}{l}28.33 \\
0.76^{\mathrm{e}}\end{array}$ & \pm & $\begin{array}{l}24.97 \\
0.15^{\mathrm{a}}\end{array}$ & \pm & $\begin{array}{l}8.90 \\
0.78^{b}\end{array}$ & \pm & $\begin{array}{l}3.48 \\
0.08^{g}\end{array}$ & \pm & $6.39 \pm 0.01^{d}$ & TNTC \\
\hline 3 & MD-CC & $\mathrm{N} / \mathrm{A}$ & $\begin{array}{l}34.00 \\
1.00^{f}\end{array}$ & \pm & $\begin{array}{l}32.56 \\
0.41^{f}\end{array}$ & \pm & $\begin{array}{l}10.50 \\
0.10^{c}\end{array}$ & \pm & $\begin{array}{l}2.50 \\
0.01^{d}\end{array}$ & \pm & $6.55 \pm 0.04^{e}$ & $34.00 \times 10^{2}$ \\
\hline 4 & MD-DD & $\mathrm{N} / \mathrm{A}$ & $\begin{array}{l}39.20 \\
0.82^{g}\end{array}$ & \pm & $\begin{array}{l}31.10 \\
0.10^{\mathrm{e}}\end{array}$ & \pm & $\begin{array}{l}10.27 \\
0.11^{\mathrm{c}}\end{array}$ & \pm & $\begin{array}{l}2.50 \\
0.01^{d}\end{array}$ & \pm & $6.59 \pm 0.01^{\mathrm{e}}$ & $29.00 \times 10^{2}$ \\
\hline 5 & LD-AA & 4: 1 & $\begin{array}{l}11.67 \\
0.67^{a}\end{array}$ & \pm & $\begin{array}{l}24.86 \\
0.32^{\mathrm{a}}\end{array}$ & \pm & $\begin{array}{l}7.80 \\
0.10^{\mathrm{a}}\end{array}$ & \pm & $\begin{array}{l}1.63 \\
0.15^{\mathrm{a}}\end{array}$ & \pm & $5.89 \pm 0.01^{a b}$ & $3.00 \times 10^{2}$ \\
\hline 6 & LD-BB & 3: 1 & $\begin{array}{l}12.50 \\
0.50^{\mathrm{a}}\end{array}$ & \pm & $\begin{array}{l}28.33 \\
0.63^{b}\end{array}$ & \pm & $\begin{array}{l}8.00 \\
0.05^{a}\end{array}$ & \pm & $\begin{array}{l}1.83 \\
0.08^{\mathrm{e}}\end{array}$ & \pm & $5.79 \pm 0.01^{a}$ & $2.29 \times 10^{2}$ \\
\hline 7 & LD-CC & 2: 1 & $\begin{array}{l}14.53 \\
0.45^{b}\end{array}$ & \pm & $\begin{array}{l}28.95 \\
0.05^{c}\end{array}$ & \pm & $\begin{array}{l}8.23 \\
0.15^{a}\end{array}$ & \pm & $\begin{array}{l}2.98 \\
0.02^{c}\end{array}$ & \pm & $5.85 \pm 0.02^{a b}$ & $2.06 \times 10^{2}$ \\
\hline 8 & LD-DD & 1: 1 & $\begin{array}{l}16.50 \\
0.50^{c}\end{array}$ & \pm & $\begin{array}{l}30.04 \\
0.05^{d}\end{array}$ & \pm & $\begin{array}{l}9.00 \\
0.05^{b}\end{array}$ & \pm & $\begin{array}{l}2.20 \\
0.10^{c}\end{array}$ & \pm & $5.95 \pm 0.05^{b}$ & $2.10 \times 10^{2}$ \\
\hline
\end{tabular}

\begin{aligned} \hline NB: & \\ i. & Figures are means of three replicates \\ ii. & Means in the same column bearing the same superscript are not significantly different from each other ( $P \leq \\ & 0.5) \\$. iii. & $M D-A A, M D-B B, M D-C C \& M D-D D=$ Market samples of dakuwa \\ iv. & $\angle D-A A, \angle D-B B, \angle D-C C \& \angle D-D D=\angle a b o r a t o r y$ processed samples of dakuwa \\ v. & $M . C .=$ Moisture content \\ vi. & TNTC-Too numerous to count; TPC- Total plate count \\ vii. & (G) to $(T)$ ratio = Groundnut to tiger nut ratio in dakuwa formulation in the laboratory $N / A=N \\ &$ available \end{aligned}

Table 3: Organoleptic Assessment of Market samples of Dakuwa

\begin{tabular}{lllll}
\hline Sensory factors & MD-AA & MD-BB & MD-CC & MD-DD \\
\hline Flavour & $2.90 \pm 1.10^{\mathrm{a}}$ & $2.60 \pm 0.97^{\mathrm{a}}$ & $2.90 \pm 0.74^{\mathrm{a}}$ & $4.40 \pm 1.43^{\mathrm{b}}$ \\
Appearance & $3.10 \pm 1.45^{\mathrm{a}}$ & $2.40 \pm 1.35^{\mathrm{a}}$ & $3.70 \pm 1.89^{\mathrm{a}}$ & $3.90 \pm 1.10^{\mathrm{b}}$ \\
Taste & $2.50 \pm 0.97^{\mathrm{a}}$ & $3.00 \pm 1.49^{\mathrm{a}}$ & $3.00 \pm 1.49^{\mathrm{a}}$ & $4.40 \pm 1.32^{\mathrm{b}}$ \\
Colour & $2.70 \pm 1.60^{\mathrm{a}}$ & $2.10 \pm 1.29^{\mathrm{a}}$ & $2.70 \pm 1.25^{\mathrm{a}}$ & $4.30 \pm 1.25^{\mathrm{b}}$ \\
$\begin{array}{l}\text { Texture (Mouth- } \\
\text { feel) }\end{array}$ & $3.68 \pm 1.73$ & $3.00 \pm 0.82$ & $2.60 \pm 1.35$ & $3.90 \pm 1.45$ \\
$\begin{array}{l}\text { Softness (finger- } \\
\text { feel) }\end{array}$ & $2.80 \pm 1.14$ & $2.70 \pm 1.25$ & $2.50 \pm 1.27$ & $3.50 \pm 1.51$ \\
$\begin{array}{l}\text { General } \\
\text { Acceptability }\end{array}$ & $3.30 \pm 1.06^{\mathrm{a}}$ & $2.80 \pm 0.63^{\mathrm{a}}$ & $3.10 \pm 1.37^{\mathrm{a}}$ & $4.30 \pm 0.95^{\mathrm{b}}$
\end{tabular}

i. Sensory scores are means of fifteen taste-panelists \pm standard deviations on a 7-point Hedonic sensory scale with $1=$ liked very much and $7=$ disliked very much

ii. Within each row, means with same or no superscript are not significantly different from each other $(P=$ 0.05).

Table 4: Organoleptic Assessment of Laboratory produced samples of Dakuwa

\begin{tabular}{lllll}
\hline Samples & LD-AA & LD-BB & LD-CC & LD-DD \\
\hline (G) to (T) Ratio & $4: 1$ & $3: 1$ & $2: 1$ & $1: 1$ \\
Sensory factors & & & & \\
Flavour & $3.00 \pm 1.37$ & $2.16 \pm 0.90$ & $2.26 \pm 0.93$ & $2.84 \pm 1.61$ \\
Appearance & $3.58 \pm 1.42^{\mathrm{b}}$ & $2.00 \pm 0.58^{\mathrm{a}}$ & $2.26 \pm 1.05^{\mathrm{a}}$ & $3.32 \pm 1.80^{\mathrm{a}}$ \\
Taste & $3.32 \pm 1.42$ & $2.26 \pm 1.41$ & $2.47 \pm 1.35$ & $3.00 \pm 1.80$ \\
Colour & $3.95 \pm 1.58^{\mathrm{b}}$ & $2.79 \pm 1.32^{\mathrm{a}}$ & $2.42 \pm 0.77^{\mathrm{a}}$ & $3.00 \pm 1.41^{\mathrm{a}}$ \\
Texture (Mouth-feel) & $3.68 \pm 1.73$ & $2.37 \pm 1.38$ & $2.74 \pm 0.99$ & $3.00 \pm 1.41$ \\
Softness (finger-feel) & $3.90 \pm 1.70^{\mathrm{b}}$ & $2.11 \pm 0.81^{\mathrm{a}}$ & $2.26 \pm 1.05^{\mathrm{a}}$ & $2.32 \pm 1.53^{\mathrm{a}}$ \\
General Acceptability & $3.63 \pm 1.07^{\mathrm{b}}$ & $2.32 \pm 0.67^{\mathrm{a}}$ & $2.47 \pm 0.47^{\mathrm{a}}$ & $2.90 \pm 1.33^{\mathrm{a}}$ \\
\hline
\end{tabular}

i. Sensory scores are means of fifteen taste-panelists \pm standard deviations on a 7-point Hedonic sensory scale with $1=$ liked very much and $7=$ disliked very much

ii. Within each row, means with same or no superscript are not significantly different from each other $(P=$ $0.05)$.

iii

(G) to $(\mathrm{T})$ ratio $=$ Groundnut to tiger nut ratio in dakuwa formulation in the laborator 
Table 5: Mean sensory scores (Hedonic taste) on markef9

\begin{tabular}{|c|c|c|c|c|c|c|c|c|c|c|c|c|c|c|c|c|}
\hline \multirow{2}{*}{\multicolumn{2}{|c|}{$\begin{array}{ll}\text { No } & \text { Samples } \\
& \\
& \text { Lab- } \\
\text { samples }\end{array}$}} & \multirow[t]{2}{*}{$\begin{array}{l}(\mathrm{T}) \text { to }(\mathrm{G}) \\
\text { ratio }\end{array}$} & \multicolumn{2}{|c|}{ Flavour } & \multicolumn{2}{|c|}{$\begin{array}{l}\text { Appearan } \\
\text { ce }\end{array}$} & \multicolumn{2}{|l|}{ Taste } & \multicolumn{2}{|l|}{ Colour } & \multicolumn{2}{|c|}{$\begin{array}{l}\text { Texture } \\
\text { (Mouth- } \\
\text { feel) }\end{array}$} & \multicolumn{2}{|c|}{$\begin{array}{l}\text { Softness } \\
\text { (finger- } \\
\text { feel) }\end{array}$} & \multicolumn{2}{|c|}{$\begin{array}{l}\text { General } \\
\text { Acceptabi } \\
\text { lity }\end{array}$} \\
\hline & & & & & & & & & & & & & & & & \\
\hline & LD-AA & N/A & $\begin{array}{l}3.00 \\
1.37^{\mathrm{a}}\end{array}$ & \pm & $\begin{array}{l}3.58 \\
1.42^{\mathrm{cd}}\end{array}$ & \pm & $\begin{array}{l}3.32 \\
1.42^{\mathrm{a}}\end{array}$ & \pm & $\begin{array}{l}3.95 \\
1.58^{b}\end{array}$ & \pm & $\begin{array}{l}3.68 \\
1.73^{\mathrm{bc}}\end{array}$ & \pm & $\begin{array}{l}3.90 \\
1.70^{c}\end{array}$ & \pm & $\begin{array}{l}3.63 \\
1.07^{\mathrm{cd}}\end{array}$ & \pm \\
\hline & LD-BB & N/A & $\begin{array}{l}2.16 \\
0.90^{\mathrm{a}}\end{array}$ & \pm & $\begin{array}{l}2.00 \\
0.58^{\mathrm{a}}\end{array}$ & \pm & $\begin{array}{l}2.26 \\
1.41^{a}\end{array}$ & \pm & $\begin{array}{l}2.79 \\
1.32^{\mathrm{a}}\end{array}$ & \pm & $\begin{array}{l}2.37 \\
1.38^{\mathrm{a}}\end{array}$ & \pm & $\begin{array}{l}2.11 \\
0.81^{a}\end{array}$ & \pm & $\begin{array}{l}2.32 \\
0.67^{a}\end{array}$ & \pm \\
\hline & LD-CC & N/A & $\begin{array}{l}2.26 \\
0.93^{\mathrm{a}}\end{array}$ & \pm & $\begin{array}{l}2.26 \\
1.05^{\mathrm{ab}}\end{array}$ & \pm & $\begin{array}{l}2.47 \\
1.35^{a}\end{array}$ & \pm & $\begin{array}{l}2.42 \\
0.77^{a}\end{array}$ & \pm & $\begin{array}{l}2.74 \\
0.99^{\mathrm{abc}}\end{array}$ & \pm & $\begin{array}{l}2.26 \\
1.05^{\mathrm{a}}\end{array}$ & \pm & $\begin{array}{l}2.47 \\
0.47^{\mathrm{ab}}\end{array}$ & \pm \\
\hline & LD-DD & N/A & $\begin{array}{l}2.84 \\
1.61^{a}\end{array}$ & \pm & $\begin{array}{l}3.32 \\
1.80^{\mathrm{bcd}}\end{array}$ & \pm & $\begin{array}{l}3.00 \\
1.80^{\mathrm{a}}\end{array}$ & \pm & $\begin{array}{l}3.00 \\
1.41^{a}\end{array}$ & \pm & $\begin{array}{l}3.00 \\
1.41^{\mathrm{abc}}\end{array}$ & \pm & $\begin{array}{l}2.32 \\
1.53^{a}\end{array}$ & \pm & $\begin{array}{l}2.90 \\
1.33^{\mathrm{abc}}\end{array}$ & \pm \\
\hline & $\begin{array}{l}\text { Market } \\
\text { samples }\end{array}$ & & & & & & & & & & & & & & & \\
\hline & MD-AA & 4: 1 & $\begin{array}{l}2.90 \\
1.10^{\mathrm{a}}\end{array}$ & \pm & $\begin{array}{l}3.10 \\
1.45^{\text {abcd }}\end{array}$ & \pm & $\begin{array}{l}2.50 \\
0.97^{a}\end{array}$ & \pm & $\begin{array}{l}2.70 \\
1.60^{\mathrm{a}}\end{array}$ & \pm & $\begin{array}{l}3.68 \\
1.73^{\mathrm{abc}}\end{array}$ & \pm & $\begin{array}{l}2.80 \\
1.14^{\mathrm{ab}}\end{array}$ & \pm & $\begin{array}{l}3.30 \\
1.06^{\mathrm{bc}}\end{array}$ & \pm \\
\hline & MD-BB & 3: 1 & $\begin{array}{l}2.60 \\
0.97^{a}\end{array}$ & \pm & $\begin{array}{l}2.40 \\
1.35^{\mathrm{abc}}\end{array}$ & \pm & $\begin{array}{l}3.00 \\
1.49^{\mathrm{a}}\end{array}$ & \pm & $\begin{array}{l}2.10 \\
1.29^{a}\end{array}$ & \pm & $\begin{array}{l}3.00 \\
0.82^{\mathrm{abc}}\end{array}$ & \pm & $\begin{array}{l}2.70 \\
1.25^{\mathrm{ab}}\end{array}$ & \pm & $\begin{array}{l}2.80 \\
0.63^{\mathrm{abc}}\end{array}$ & \pm \\
\hline & MD-CC & 2: 1 & $\begin{array}{l}2.90 \\
0.74^{a}\end{array}$ & \pm & $\begin{array}{l}3.70 \\
1.89^{d}\end{array}$ & \pm & $\begin{array}{l}3.00 \\
1.49^{a}\end{array}$ & \pm & $\begin{array}{l}2.70 \\
1.25^{a}\end{array}$ & \pm & $\begin{array}{l}2.60 \\
1.35^{\mathrm{ab}}\end{array}$ & \pm & $\begin{array}{l}2.50 \\
1.27^{\mathrm{ab}}\end{array}$ & \pm & $\begin{array}{l}3.10 \\
1.37^{\mathrm{abc}}\end{array}$ & \pm \\
\hline & MD-DD & $1: 1$ & $\begin{array}{l}4.40 \\
1.43^{b}\end{array}$ & \pm & $\begin{array}{l}3.90 \\
1.10^{\mathrm{d}}\end{array}$ & \pm & $\begin{array}{l}4.40 \\
1.32^{\mathrm{b}}\end{array}$ & \pm & $\begin{array}{l}4.30 \\
1.25^{b}\end{array}$ & \pm & $\begin{array}{l}3.90 \\
1.45^{c}\end{array}$ & \pm & $\begin{array}{l}3.50 \\
1.51^{\mathrm{bc}}\end{array}$ & \pm & $\begin{array}{l}4.30 \\
0.95^{d}\end{array}$ & \pm \\
\hline
\end{tabular}

NB:

i. $\quad$ Figures are means of three replicates

ii. Means in the same column bearing the same superscript are not significantly different from each other ( $P \leq$ $0.5)$.

iii. $M D-A A, M D-B B, M D-C C \& M D-D D=$ Market samples of dakuwa

iv. $\quad L D-A A, \angle D-B B, \angle D-C C \& \angle D-D D=\angle a b o r a t o r y$ processed samples of dakuwa

v. (T) to $(G)$ ratio = Tiger nut to groundnut ratio in dakuwa formulation in the laboratory $N / A=N o t$ availabl

Comparison between the mean sensory scores of market and laboratory samples of Dakuwa is shown in table 5. Significant differences were observed for all the sensory parameters $(P \leq 0.05)$. Except for the market sample MD-DD, no other Dakuwa samples have any sensory score above 4.0 i.e. neither liked nor disliked. Also, laboratory samples produced from 2:1 and 3:1 tiger nut to groundnut ratio in Dakuwa formulation were rated the best.

\section{Conclusion}

Survey results on methods of dakuwa production showed non-uniformity among different types of dakuwa producers. This was also reflected in the

\section{REFERENCES}

Bagirei, S. Y. and Adegoke G. O. (2008). Effect of roasting and Aframomun Danielli extract on aflaxoin level of "Dakuwa" an Indigenous snack. NIFOJ Vol 26.

Nuru, S. (1985) Stratergies for production of flesh foods in Nigeria, Technology for the Tropics. First Edition Mainlia Publishers London.

Ocheme, O.O; Ariahu, C. C; Igyor, M. A (2011): Assessment of Traditionally Produced Dakuwa (A Cereal/Legume Based Nigerian Snack) in Niger State, Nigeria. Nigerian Food JournalVol 29, No 1 (2011)

Abodurin, O. A. and Belewu M. A. (2008) Preparation of kunu from unexploited rich food source: Tiger nut (cyperus esculentus).Pak. J. Nutri. 7;109111 physicochemical and organoleptic attributes of the different Dakuwa market samples. For the laboratory processed samples using four ratios of groundnut to tiger nut $(1: 1,2: 1,3: 1$ and $4: 1)$ it was found out that as the quantity of groundnut increased, the texture of the Dakuwa became stickier. Also the total plate count of all the laboratory dakuwa samples were within the acceptable limit $10^{2}$ to $10^{3} \mathrm{cfu} / \mathrm{ml}$ as reported by Adams and Moss (1999). Finally, Dakuwa produced from ratios $3: 1$ of groundnut to tiger nut was found to be the best overall in general acceptability, flavor, appearance, and color for both market and laboratory Dakuwa samples.

Okaka, J.C. (1997). Cerals and Legumes; Storage and processing Technology. Data and mocrosystems publication Enugu- Nigeria.

Kirk R.S, (1991). Pearson's composition and analysis of food, ninth edition. Chemical publishing Co. Inc., New York.

AOAC (1990). Association of Official Analytical Chemist, official method of Analysis.14 ${ }^{\text {th }}$ edition Washington D.C.

Diliello L.R (1982) Methods in food and dairy microbiology AV. Publishing co. MC:Westport Connecticut. pp49-5

Adams,M.R. (1999) food microbiology. The Roray Society of Chemistry $(\mathrm{C})$. Published by the Roray Society of Chemistry, Cambridge. Pp.123, 103-219. 